\title{
Kant Yearbook
}

$12 / 2020$ 



\section{Kant Yearbook $12 / 2020$ Kant and Neo-Kantianism}

\section{Edited by}

Dietmar H. Heidemann (University of Luxembourg)

\section{Editorial Assistant:}

\section{Sven Seidenthal (University of Luxembourg)}

Editorial Board:

Henry E. Allison (University of California, San Diego), Karl Ameriks (Notre Dame), Gordon Brittan (Montana State University), Daniel O. Dahlstrom (Boston University), Klaus Düsing (Universität zu Köln), Corey Dyck (University of Western Ontario), Kristina Engelhard (Universität Trier), Brigitte Falkenburg (TU Dortmund), Hannah Ginsborg (University of California at Berkeley), Michelle Grier (University of San Diego), Thomas Grundmann (Universität zu Köln), Paul Guyer (Brown University), Robert Hanna (Independent Philosopher), Markus Kohl (Chapel Hill), Lothar Kreimendahl (Universität Mannheim), Guido Kreis (Aarhus University), Georg Mohr (Universität Bremen), Angelica Nuzzo (Brooklyn College/CUNY), Dieter Sturma (Universität Bonn), Robert Theis (University of Luxembourg), Jens Timmermann (University of St Andrews), Ken Westphal (Boğaziçi Üniversitesi), Marcus Willaschek (Universität Frankfurt/Main)

\section{DE GRUYTER}


The Kant Yearbook is an international journal that publishes articles on the philosophy of Immanuel Kant. Each issue is dedicated to a specific topic. Each annual topic will be announced by way of a call for papers. The Editorial Board of the Kant Yearbook is composed of renowned international experts, and selects papers for publication through a double blind peer review process.

Online access for subscribers: http://dx.doi.org/10.1515/kantyb

ISSN $1868-4599$ (Print)

ISSN 1868-4602 (Online)

Bibliographic information published by the Deutsche Nationalbibliothek

The Deutsche Nationalbibliothek lists this publication in the Deutsche Nationalbibliografie; detailed bibliographic data are available on the Internet at: http://dnb.dnb.de.

(c) 2020 Walter de Gruyter GmbH, Berlin/Boston

Cover image: Martin Zech, Bremen

Printing and binding: CPI books $\mathrm{GmbH}$, Leck

www.degruyter.com 